\title{
Evaluation Tools for Scientific Research Professionals: A Contribution to the Strategic Planning of R\&D Institutions
}

\author{
Celso Huerta Gimenes, Delvonei Alves de Andrade \\ Institute of Energy and Nuclear Research, São Paulo, Brazil
}

Luiz Silva dos Santos

InstituteUniversity Nine of July, São Paulo, Brazil

\begin{abstract}
In the Brazilian public sector, the performance evaluation of public servants was not regulated in the late 20th century. The literature review showed that there are several methods for the implementation of this practice, although none of them fits the evaluation of the productivity of researchers and technologists. This fact justifies the present work, which aims to identify a set of researchers and technologists productivity indicators and, from them, compose and validate a multidimensional model for the performance evaluation of professionals working in scientific research. Two methodological approaches were used for the quantitative and qualitative assessment. The model is flexible because it allows evaluating the academic production in the service area, teaching, production, and development, and can be applied/adapted in any area of knowledge. The results present the indicators that are most valued by respondents as to their productivity evaluation, showing, also, the intrinsic and extrinsic professional satisfaction factors perceived by researchers and technologists of Institute of Energy and Nuclear Research.
\end{abstract}

Keywords: performance evaluation, satisfaction factors at work, academic productivity indicators

The evaluation of people in the business context is often associated with a specific management tool: the performance evaluation. Pronouncing the term evaluation is enough to make people think about this instrument, the purpose of which is to verify how much a professional meets the company goals and the job demands and requirements (Hippolytus \& Reis, 2002).

In the academic and technological environment researched, this perception is not different. However, there is no room for flexibility as in the private sector. The top management sponsorship is characterized by the lack of credibility on the evaluation methodologies.

Hence, to reward good researchers and technologists or to punish those who are bad professionals is not always possible. For Fernando (2006), public servants are not punished for poor performance, even for illegal conduct. In general, they appear to be discouraged and accommodated, with much smaller quest for results, especially because employment and wages are ensured.

Corresponding author: Celso Huerta Gimenes, MA in administration, human resources management, Institute of Energy and Nuclear Research; research field: human resources management. E-mail: cgimenes@ipen.br.

Delvonei Alves de Andrade, PhD in nuclear technology, mechanical engineering, Institute of Energy and Nuclear Research; research field: reactor technology and human factors applied to the nuclear technology. E-mail: delvonei@ipen.br.

Luiz Silva dos Santos, MA in business and administration, Institute University Nine of July; research field: administration. E-mail: luizsilvadossantos@uninove.edu.br. 
In Brazil, scientific research is mainly concentrated in the Estate Hands and the Estate, since the Portuguese Empire, has always had difficulty distinguishing between the public and the private, what has reflected in the provision of positions. With the reform of the state, which began in the 1930s, the administration had its functions divided and streamlined, although the performance evaluation was only made official with the Federal Constitution of 1988 and the Law 8.112/90, which created the Unique Legal Regime (Regime Jurídico Único) of the union servants. In 2008, with the enactment of the Provisional Measure No. 431, converted into Law 11.784 in September of that year, and the Decree 7.133 of March 19, 2010, there was the regulation of the general criteria and procedures for conducting evaluations of individual and institutional performance and the payment of performance bonuses.

Given the scenario presented, this study is justified, analyzing the academic and technological productivity and presenting a multidimensional methodology performance evaluation, focusing on the level of productivity of scientific researchers and technologists.

\section{Theoretical Fundaments}

The practice of performance evaluation implies a systematic process of data collection, guided by established and well-known criteria by the actors involved in the process, allowing the formation of a trial of evidence-based value (Reifschneider, 2007), and the decision-making related to the staff development and planning. This process requires that the employees participate in the development of indicators and data collection to demonstrate their performance. However, often, instead of a performance evaluation what occurs is a value judgment, without factual basis, defined or valid criteria, commonly reported to the employee post factum. Such an attitude, due to the lack of preparation and understanding of the process by managers, besides the lack of an institutional framework for evaluation and training, leads to employee dissatisfaction.

It is necessary to avoid the risk of building instruments based solely on personality traits (initiative, politeness, and others), more susceptible to errors of judgment than those factors related to productivity or quality of work.

Formal performance evaluation programs are not new. According to Chiavenato (2005), "Before the Jesus Society Foundation (Fundação da Companhia de Jesus), St. Ignatius Loyola was already using a combined system of activity reports and notes and, mainly, the potential background of each of his Jesuits". For Bohlander, Snell, and Sherman (2003), "The American federal government began to evaluate employees in 1842 , when the congress approved a law making the annual performance reviews mandatory for employees of the department". The traditional systems of performance assessment began to be disseminated and applied by organizations from the Second World War on. From 1954, with the work of Peter Drucker, The Practice of Management, a new management guidance entitled "Management by Objectives_PDB" became popular, with processes that led to a new concept of evaluation - the evaluation by objectives. In Brazil, this concept of evaluation had several branches. In 1986, the first edition of that book was published, presenting alternatives to the performance evaluation based on targets.

For Pontes (2010), a formal program of performance evaluation has the following main objectives:

(1) Making the planning of the organization dynamic;

(2) Achieving improvements in the organization with focus on productivity, quality, and customer satisfaction, as well as regarding economic and financial matters;

(3) Improving people and organization skills, developing people; 
(4) Establishing expected results from people;

(5) Obtaining the commitment of people in relation to the results aimed by the organization;

(6) Improving communication among the hierarchical levels, creating constructive dialogue climate, and eliminating dissonances, anxieties, and uncertainty;

(7) Giving constant guidance on the performance of people, seeking improvements;

(8) Making it clear that results are achieved by the action of the corporate body;

(9) Establishing a climate of trust, motivation, and cooperation among members of work teams;

(10) Serving as a propagator instrument of quality programs and, according to the adopted method, of the own quality management tool;

(11) Serving as an important supporting instrument in career decisions, wages, and participation in the company results;

(12) Serving as a tool for raising training and development needs;

(13) Identifying talents as a joint process together with the potential evaluation instrument.

For the same author, the methods of performance evaluation are classified as shown in Table 1.

Table 1

Methods Classical and Contemporary

\begin{tabular}{|c|c|c|c|}
\hline \multicolumn{2}{|c|}{ Classical methods } & \multicolumn{2}{|c|}{ Contemporary methods } \\
\hline Evaluation emphasis: past & Evaluation emphasis: future & $\begin{array}{l}\text { Evaluation emphasis: past and } \\
\text { future }\end{array}$ & Evaluation emphasis: future \\
\hline $\begin{array}{l}\text { Field research } \\
\text { Critical incidents } \\
\text { Descriptive sentences } \\
\text { Graphic scale } \\
\text { Forced scale } \\
\text { Binary comparison } \\
\text { Grades assignment }\end{array}$ & $\begin{array}{l}\text { Evaluation by objectives } \\
\text { Evaluation of activities }\end{array}$ & Competences & $\begin{array}{ll}\text { Results monitoring } \\
\text { evaluation }\end{array}$ \\
\hline
\end{tabular}

Note. Source: Pontes (2010).

The classical methods, with evaluation emphasis in the past, have resulted in a bad evaluation, requiring a great deal of care in their application due to the subjectivity of the criteria. The methods that emphasize the future are useful and valid once the assessment contains more objective criteria. Between the two methods presented, one of them is highlighted, the method of evaluation by objectives, as it is directly related to the strategic objectives of the organizations.

\section{Concept}

The evaluation is a cyclical process, marked by three moments: the "before" establishing planning, the "during" that accompanies and supervises the implementation of what was planned, and the "afterwards", when what was planned and what has been executed are accounted for and re-scheduled. Based on this principle, the performance evaluation process comprises the so-called, in the organizational theory, "management cycle", what consists of the functions: planning, organizing, coordinating, and controlling (Maximiniano, 1995).

It is a commonplace process in people's lives, in all circumstances and times, to be evaluating everything happening around us. The same occurs in organizations, where there is the need to evaluate the different performances_-financial, operational, technical, and human (Chiavenato, 1999). 
Evaluating, according to Rabaglio (2004), means making an analysis to review processes, improve behaviors and techniques, figure out a way to do different tasks, always looking for effective results.

The performance evaluation is a powerful way to resolve performance issues and improve both, the quality of work and the quality of life (Chiavenato, 1999). Through this tool, human performance is identified, measured, and managed. The identification refers to the analysis of positions and definitions of what should be evaluated. The measurement relates to what standard the performance should be compared with. Finally, management is the key aspect of the whole evaluation system.

\section{Definitions}

To study and develop this work, the theory of Maturity-Immaturity, developed by Chris Argyris (1968), was adopted, providing the basis for many authors to formulate the concept of personal and organizational maturity. According to this theory, professionals are mature when they present the following characteristics: They are active (having initiative, proposing); they are independent (opening spaces, demonstrating autonomy); their behaviors are varied and consistent with the stimuli that the external environment offers; their interests are more intense and deeper; their prospects for action are medium and long term (with leadership and vision); they have an attitude of equality or superiority, in the context of the organization, with the manifestation of their self-esteem; they have strong personal control when facing facilitating or restrictive variables of action.

The maturity of a process is related to the degree of its efficiency and effectiveness and how it is integrated with other processes. Processes with greater maturity are strongly aligned with the objectives and the strategy of the organization.

Owing to the fascination and provocation that research on maturity have triggered the scholars over the years, 34 models are found, among which we highlight the People Capability Maturity Model (P-CMM) that allows management of people, according to Silveira (2009).

For Rodrigues, Tarouco, and Klering (2012), the idea of maturity, a concept that became widely known through the Capability Maturity Model (CMM) or model of the Software Capability Maturity, originated with the theory of Chris Argyris.

The theory above was, also, identified in the judgment criteria for grants from the National Council for Scientific and Technological Development-CNPq, in the three-year periods 2006/2008 and 2009/2011, when independence and scientific maturity was sought (for academic grants) including, therein, an appreciation of the scientific research scope (opposed to excessive specialization).

Based on the presented concepts, it can be said that both, the maturity of the researcher and of the scientific technologist are related to the time and amount of what has been produced during their lifetime, according to CNPq criteria, mentioned above, which may be understood as:

A set of knowledge, skills and attitudes, shown in a scientific context, in a given period of time and reflected in: training of human resources; scientific, technological and innovative contribution; coordination or participation in projects and/or research networks; participation in editorial activities, scientific management, management of institutions and scientific and technological excellence centers; ability to raise capital; and interaction with the industrial park.

Taking into account the importance of knowledge management, nowadays, for the organization survival, some management paradigms of this intangible capital were modeled. One of them, conceived by the Business Intelligence Reference Center of the Federal University of Rio de Janeiro (Create-Coppe/UFRJ), has four standpoints, which should be monitored and managed for the effective knowledge management in the 
organization: environmental capital, structural capital, human capital, and relationship capital, as shown in Figure 1.

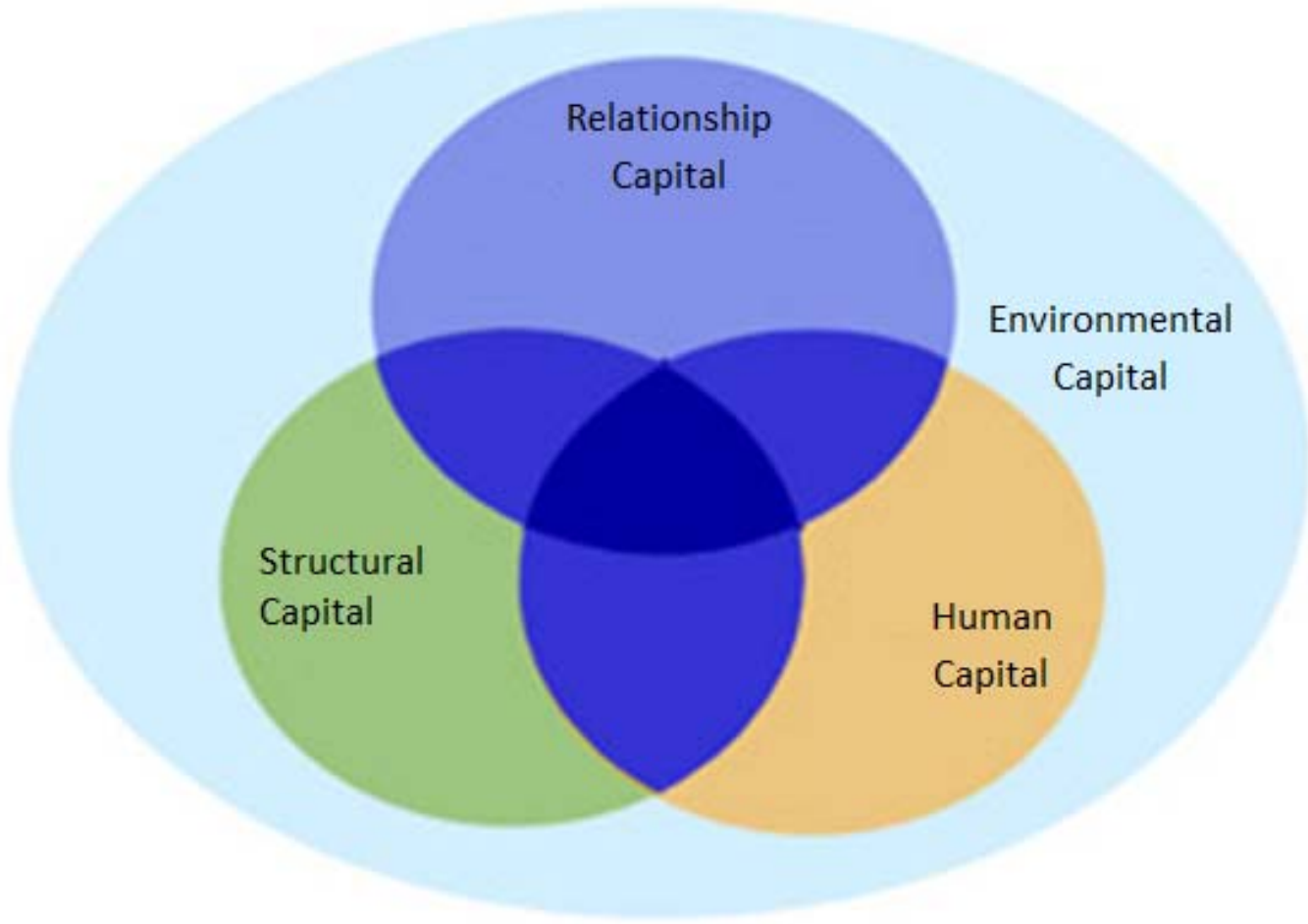

Figure 1. Crie, Coppe/UFRJ.

All four capitals are equally important, as the company growth depends on the synergy among them. However, the relative importance of this interaction depends on the degree of development and the type of business the organization is involved with (Create, Coppe/UFRJ). Thus, the definitions of human capital, structural capital, and relationship capital, used by Crie, were used in this work, but more broadly, as described below. The environmental capital was not an object of study.

Human capital. Human capital is a major wealth-generating asset in companies. The value of each individual contributes to the growth of the organization and may be increased or depreciated in accordance with the policies and management practices applied. With the ever-changing economic environment, the persons have, definitely, become a competitive advantage, making it clear the demand from organizations for new tools and management strategies where the idea of "personnel costs" is replaced by "investment in human capital".

Structural capital. The structural capital can be defined as a set of administrative systems, concepts, models, patterns, brands, patents, and computer systems, which allow the organization to function effectively and efficiently. The organizational culture is part of the structural capital, or, in other words, the way an organization operates its business. The structural capital is composed of items that now belong to the company, represented by its explicit intangible assets. When the tacit knowledge of an employee is captured and stored, it becomes part of the structural capital. This capital consists of technology, inventions, data, files, repositories of knowledge, publications, processes and programs that, altogether, record the knowledge of the organization.

Relationship capital. It is formed by the organization network of relationships with customers, suppliers, and partners. These relationships may be individual or institutional. The interaction among the different sources 
of the knowledge capital is the very source of wealth of organizations. It shows that the structural capital may increase the intellectual capital, as long as the organizations have a training center, where members learn new techniques and languages.

\section{Productivity}

The concept of human capital, or more extensively, human resources — seeks to translate the amount of investment that a nation or individuals make, expecting future revenue. From a macroeconomic point of view, investment in "human factor" now means one of the basic determinants for increasing productivity and an element to overcome economic backwardness. From the microeconomic point of view, it constitutes the explanatory factor of individual differences in productivity and income and, consequently, in social mobility (Debora, 2014).

\section{Care on Assessment}

Recommendation to avoid errors of judgment is: central tendency, bias, similarity, contrast, leniency, recency, logical, and halo. According to Vasconcelos and Kruglianskas (1991), among other complicating factors of this process, there is a lack of tradition in formal performance evaluation in our institutions, of their respective administrators and financing agents. Another complicating aspect refers to the fact that research institutions board is usually represented by reputable professionals with high scientific training, a factor that can lead them to emphasize on the technical and scientific aspects of evaluation, to the detriment of administrative aspects, resulting in the tendency of the institutions to develop research more linked to the interests of the professionals than to the real needs of the country.

\section{A Conceptual Model}

Based on the theoretical framework presented and aiming at evaluating academic and technological production of scientific researchers and technologists, verifying the indicators most valued by them, Figure 2 below shows the adapted conceptual model of Coda (1986):

Intrinsic factors: autonomy, variety, significance, feedback, and identity.

Extrinsic factors: financial reward, benefits, others, professional recognition, promotion and supervision (Coda, 1986).

Issues related to the conceptual model ratified in this study were:

(1) There are differences in the perception of the academic and technological production, inside the group of scientific researchers and technologists;

(2) There are differences in the perception of the academic and technological production, by area of knowledge of scientific researchers and technologists;

(3) Individual characteristics of scientific researchers and technologists, according to the positions they hold, besides their academic status, influence in the value they give to the academic and technological production.

As stated by Wallace and Szilagyi (1982), cited by Coda (1986), the influence of rewards on the behavior and performance is equally dynamic. The satisfaction with the rewards may be considered as a critical factor for organizations to achieve their goals with compensation policies, such as, for example, collaborators retention and motivation. If managers understand the antecedents of satisfaction with the rewards, they may influence the satisfaction levels perceived by their employees more easily (Susana, Filipa, Ana, Nelson, \& Antonio, 2009). 
Thus, changes in the policies and practices of rewards can cause changes in the behavior and performance, since the employees are aware of the existing policies and practices of rewarding and will adjust their behavior to them.

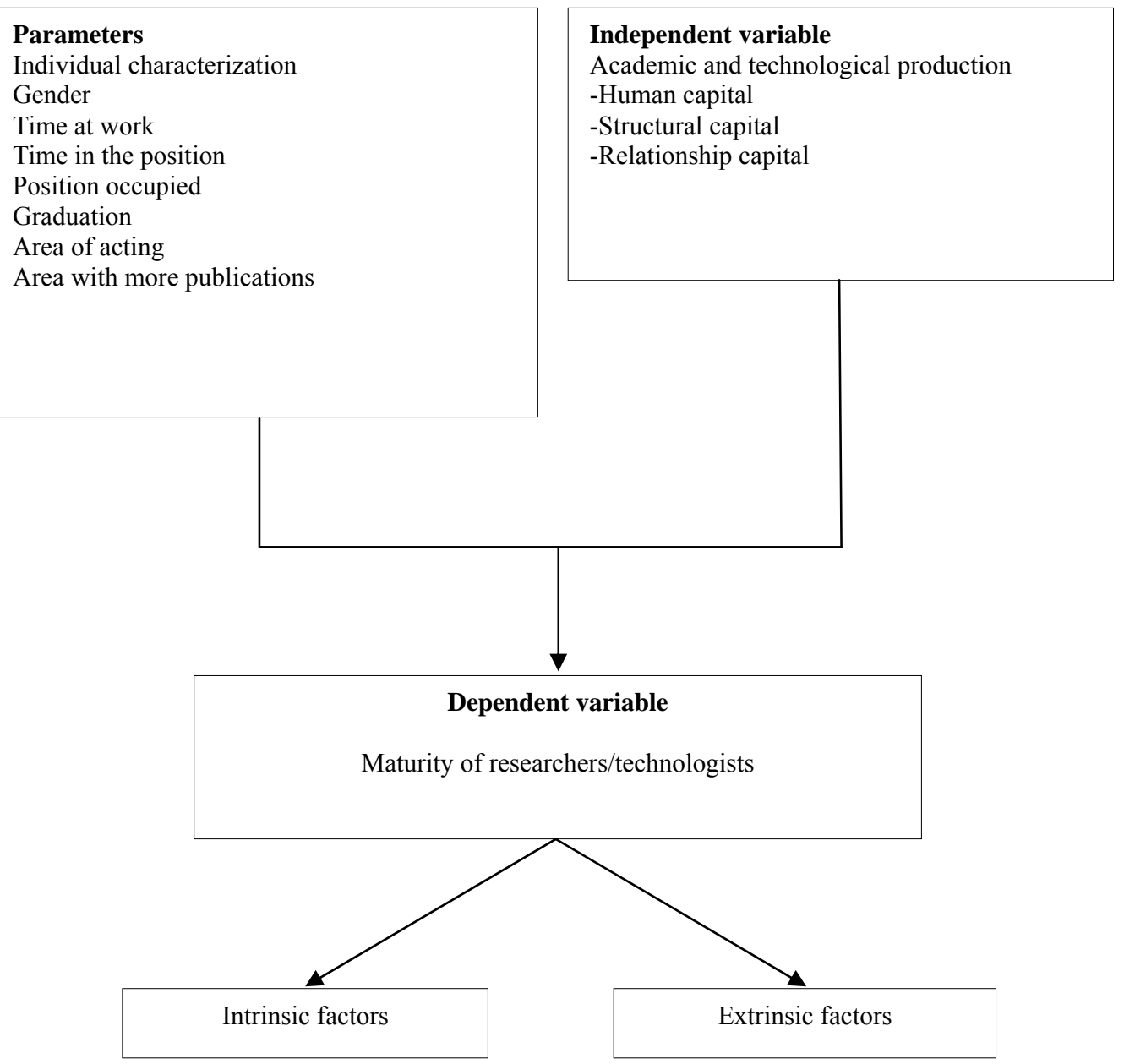

Figure 2. Conceptual model for the performance evaluation of scientific researchers and technologists. Source: Adapted from Coda (1986).

\section{Methodology}

This section presents decisions and methodological procedures followed in the development of research. The study was divided into two phases. In the first phase, the literature review was undertaken in order to build a consistent basis for the study. The production of the construct was based on the indicators used by development agencies, research institutes, and universities. The methodology was specific to the assessment of scientific researchers and technologists and beyond attributions, graduations, titles and time of work are considered.

Hence, researchers and technologists answered the questionnaire containing 41 academic productivity indicators. For better understanding and coherence with what was being investigated, the definition of each of the different types of capital in question opens the indicators of each capital. Considering human capital, structural capital and relationship capital definitions and the notion of comparison and equivalence, values ranging from 01 to 07 , were requested to be given to the questions assigned. 
Three dimensions were identified, related to the perception researchers and technologists had about the management of knowledge, namely:

(1) The first dimension (VL1) considers the relevance of academic productivity, verifying the notion of comparison and equivalence for 17 observable variables related to the human capital;

(2) The second dimension (VL2) considers the relevance of academic productivity, verifying the notion of comparison and equivalence for eight observable variables related to the structural capital;

(3) The third dimension (VL3) considers the relevance of academic productivity, verifying the notion of comparison and equivalence for 14 observable variables related to the relationship capital.

\section{Assessment Tool}

Firstly, an interview script was applied for a group of 15 researchers and scientific technologists. The goal was to offer them the opportunity to express their opinions and ideas on various elements present in the workplace, in order to identify attitudes and feelings.

In the second phase, the questionnaire of quantitative research was submitted, initially, to a group of 30 employees from diverse backgrounds, but who did not belong to academia, in order to verify the clarity of information. In a third step, the instrument was addressed to a group of $\mathrm{PhD}$ professors from different areas of knowledge, in order to verify and correct possible inconsistencies and lack of precision.

During the debugging phase, in addition to the groups of researchers and technologists and to demographic aspects of the population, some items were outlined: (1) age; (2) sex; (3) graduation ranking; (4) titles; (5) working time in the organization; (6) position; (7) area of operation; and (8) area of knowledge with more publications. The criterion used for this segmentation was the requisite to know what the respondents mostly value, for area of knowledge.

After adjustments had been made by the group of collaborators and the population and the methodology had been defined, a pre-test was conducted. The sample was drawn, at random, for 72 scientific researchers and technologists, with a return of 68 , or $94 \%$. The questionnaire was, also, sent to CNPq Advisory Committee, composed of 10 members, with the return of $40 \%$, amounting at this stage, 72 completed questionnaires.

\section{Application}

After the preliminary procedures of the instrument adjustments, evaluation by professor-doctors and the pre-test, the questionnaire was applied to 352 Institute of Energy and Nuclear Research researchers and scientific technologists. The non-probabilistic sample was defined by accessibility, and the collection was held in July and August 2014; for the management of the research, Limesurvey program ${ }^{1}$, was chosen for having the following characteristics: It is a software that enables the import and export of data; it has a declarative survey language for database, of great simplicity and easy use plus the fact of being free. The link to the survey data collection instrument was sent to researchers and technologists via email.

As a development criterion of the data collection instrument, it was sought a result of, at least, $70 \%$ of answers return, in each of the following stages: Instrument debugging (sample chosen for convenience), pre-test (sample drawn at random), and instrument application (total population of researchers and technologists).

In the second phase of the research, the data were analyzed with the help of the Statistical Package for Social Sciences (SPSS) software, according to Marôco (2007).

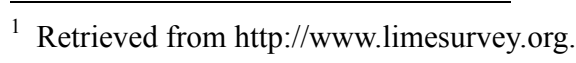


For data analysis, the significance level of $5 \%(0.05)$ for the $95 \%$ confidence interval was adopted; the internal consistency analysis adopted was general Chronbach $\alpha$ of 0.965 .

\section{Intracapital Consistency}

By taking, for example, the human capital, the $19 \times 259$ matrix is obtained (human capital consists of 19 variables $\times 259$ respondents), which calculated the mean, standard deviation and the $\alpha$ of Chronbach. The other two Chronbach coefficients were calculated, analogously, for the other capitals of knowledge surveyed.

\section{Analysis of Results}

The survey was conducted with researchers and technologists from diverse backgrounds, such as: physicists, chemists, various types of engineering, statisticians, pharmacists, and biologists. The analysis was performed with 259 inputs and, based on non-zero entries, the following data may be concluded: It can be said that, among the researchers and scientific technologists who responded to the survey, there is a predominance of males, over the age of 50 years, with high level of education and with over 20 years of experience. As for the position, the predominance is for scientific technologists. As to the area of activity, research and development prevails.

For analysis of the concept of comparison and equivalence for the 41 indicators, related to the factors: human capital, structural capital, and relationship capital, measures of central tendency and dispersion were evaluated in the three variables that make up the construct. On a 7-point scale, for the group of respondents comprised of 105 researchers and 154 technologists, it was observed in the quantitative research, in general distribution, that the most valued indicator was the merit of publishing a book, with a range of four (minimum) to seven (maximum) points, in the adopted scale. The values for the mean and standard deviation are, 6.65 and 0.73 , respectively.

When the group of respondents is divided between researchers and technologists, the same rating to the variable related to the worth of publishing a book is observed, showing the same maturity. The values for the mean and standard deviation are, practically, imperceptible, averages of 6.65 and 6.57 and standard deviation of 0.73 and 0.89 , respectively.

It may be, also, observed the maturity of the respondents when the questionnaire was segmented as for human capital, structural capital, and relationship capital: Researchers and technologists valorize the same variable: What publishing a book is worth.

Considering all respondents, $\alpha$ of Chronbach was calculated for each knowledge capital researched. The results are as follows.

\section{Stratification of Knowledge Capital}

(1) Human capital-0.924;

(2) Structural capital-0.916;

(3) Relationship capital -0.932 .

The result above shows the consistency indices of ratings considering all respondents. This index could also be estimated for each characteristic of respondents: Age, gender, graduation, schooling (title), working time, and position.

Table 2 shows the stratified $\alpha$ Chronbach for the positions of researchers and technologists. 
Table 2

Consolidated Vision-Consistency Index ( $\alpha$ Chronbach)

\begin{tabular}{lll}
\hline Types of capital & Researcher & Technologist \\
\hline Human capital-HC09 to HC26 & 0.932 & 0.912 \\
Structural capital-SC27 to SC34 & 0.914 & 0.909 \\
Relationship capital—RC35 to RC41 & 0.933 & 0.917 \\
\hline
\end{tabular}

Despite being a widely used indicator as a measure of inter-consistency, there are some precautions that should be observed when setting up conclusions.

(1) The Chronbach $\alpha$ has a positive relationship with the number of items evaluated; therefore, a construct with five or more sampled variables tends to produce larger $\alpha$ 's than one with only three. Therefore, in the case of eight variables only, as in the structural capital, the test becomes "more demanding" than in the case of "human" capital, which has 18 variables;

(2) This test is, also, less reliable when the variable is little sampled, what is not the case of the present work that has 259 respondents. When the sample is small, $\sigma_{i, j}^{2}$ variance tends to be slightly larger, what tends to reduce $\alpha_{i}$.

From the final set of the 41 indicators, two products of this work were extracted:

(1) Identifying in the scientific production researched, the most valued items for researchers and technologists, from the descriptive statistics (mean, standard deviation, and variance), as well as Chronbach $\alpha$;

(2) Establishing matrices for performance evaluation by family, namely:

By assignment, researchers, technologists; by professional performance: research and development, production and services; by graduation: physics, chemistry, mechanical engineering, electrical engineering, chemical engineering, biological sciences and other engineering branches; by degree: specialization, master's, and doctorate.

Table 3 shows descriptive statistics for researchers and scientific technologists.

Table 3

Descriptive Statistics for Researchers and Scientific Technologists

\begin{tabular}{|c|c|c|c|c|c|}
\hline Indicators & Min. & Max. & Mean & Std. deviation & Variance \\
\hline Rank the offer of a graduation discipline & 1 & 7 & 5.02 & 1.52 & 2.32 \\
\hline Rank the offer of a post-graduation discipline & 2 & 7 & 5.94 & 1.18 & 1.39 \\
\hline Rank the doctorate advice concluded & 2 & 7 & 6.39 & 1.04 & 1.08 \\
\hline Rank a doctorate advice in progress & 2 & 7 & 5.33 & 1.32 & 1.75 \\
\hline Rank the curriculum internship in progress & 1 & 7 & 4.18 & 1.74 & 3.06 \\
\hline Rank the scientific initiation concluded & 1 & 7 & 4.60 & 1.70 & 2.91 \\
\hline Rank the scientific initiation in progress & 1 & 7 & 4.01 & 1.80 & 3.25 \\
\hline Rank the master degree concluded & 2 & 7 & 5.74 & 1.17 & 1.37 \\
\hline Rank the master's advice in progress & 2 & 7 & 5.03 & 1.41 & 2.01 \\
\hline Rank the post-doctorate advice concluded & 1 & 7 & 5.70 & 1.45 & 2.12 \\
\hline Rank research concluded & 2 & 7 & 6.49 & 0.92 & 0.84 \\
\hline Rank research in progress & 2 & 7 & 5.50 & 1.27 & 1.62 \\
\hline Rank to publish an article in an international journal & 2 & 7 & 6.27 & 1.12 & 1.25 \\
\hline Rank to publish an article in a national journal & 1 & 7 & 4.96 & 1.44 & 2.09 \\
\hline Rank an abstract for an international event & 1 & 7 & 4.36 & 1.66 & 2.78 \\
\hline
\end{tabular}


Table 3 continued

\begin{tabular}{|c|c|c|c|c|c|}
\hline Indicators & Min. & Max. & Mean & Std. deviation & Variance \\
\hline Rank a paper/an abstract for a national event & 1 & 7 & 3.64 & 1.77 & 3.13 \\
\hline Rank a full paper for an international event & 1 & 7 & 5.50 & 1.54 & 2.38 \\
\hline Rank a full paper for a national event & 1 & 7 & 4.75 & 1.69 & 2.87 \\
\hline Rank to publish a chapter in a book & 2 & 7 & 5.53 & 1.20 & 1.44 \\
\hline Rank to publish a book & 2 & 7 & 6.61 & 0.83 & 0.69 \\
\hline Rank the application to register an international patent & 1 & 7 & 6.39 & 1.02 & 1.05 \\
\hline Rank the application to register a national patent & 1 & 7 & 5.69 & 1.42 & 2.01 \\
\hline Rank the value of a technological product & 1 & 7 & 6.08 & 1.27 & 1.63 \\
\hline Rank a concluded project & 1 & 7 & 6.25 & 1.09 & 1.20 \\
\hline Rank a project in progress & 2 & 7 & 5.18 & 1.33 & 1.77 \\
\hline Rank the production of a technical report & 1 & 7 & 4.70 & 1.76 & 3.12 \\
\hline Rank raising external funds/resources & 1 & 7 & 6.18 & 1.05 & 1.11 \\
\hline Rank customers capture & 1 & 7 & 5.64 & 1.48 & 2.20 \\
\hline Rank the organization or coordination of events & 1 & 7 & 5.32 & 1.35 & 1.83 \\
\hline Rank the capture of international partnership & 1 & 7 & 6.15 & 1.12 & 1.26 \\
\hline Rank a national partnership capture & 1 & 7 & 5.67 & 1.34 & 1.81 \\
\hline Rank the participation in an external board of examiners & 1 & 7 & 5.06 & 1.63 & 2.68 \\
\hline Rank the participation in an internal doctorate board of examiners & 1 & 7 & 4.69 & 1.68 & 2.83 \\
\hline Rank the participation in an external master's board of examiners & 1 & 7 & 4.63 & 1.68 & 2.85 \\
\hline Rank the participation in an internal master's board of examiners & 1 & 7 & 4.31 & 1.74 & 3.03 \\
\hline Rank the participation in an editorial commission, council & 1 & 7 & 5.09 & 1.52 & 2.34 \\
\hline Rank the participation in the commercialization of products & 1 & 7 & 4.88 & 1.68 & 2.85 \\
\hline Rank the maintenance of products in catalogues & 1 & 7 & 4.45 & 1.66 & 2.78 \\
\hline Rank the participation in the launching of a new product in the year & 1 & 7 & 5.15 & 1.75 & 3.06 \\
\hline Rank the maintenance of services in catalogues & 1 & 7 & 4.50 & 1.67 & 2.81 \\
\hline Rank the participation in the launching of new services in the year & 1 & 7 & 4.95 & 1.74 & 3.06 \\
\hline
\end{tabular}

\section{Intergroup Consistency (Indicators)}

To assess whether the indicators were consistently scored, mean, standard deviation, and variance for each of the three capitals of knowledge surveyed were calculated.

\section{Conclusions}

This study sought to identify the most valuable indicators of academic productivity, in the perception of scientific researchers and technologists.

For this purpose, a field survey was conducted with 259 research scientists and technologists, whose performance evaluation is managed by traditional methodology.

The analysis of the results reveals that there are differences, in the perception of researchers and in that of technologists, in relation to the academic and technological production; there are differences in the perception of the academic and technological production, by area of knowledge of these scientific researchers and technologists. It was, also, detected that individual characteristics of researchers and technologists, as the positions they hold and their academic background, influence the academic and technological production value.

It is, also, noteworthy that the ranking of motivational factors shows that both intrinsic and extrinsic aspects should be used with greater acuity in the management of human resources, in R\&D (research and development) institutions. Intrinsic factors concern: responsibility for the work; performance of interesting and 
different tasks from those required for the position; perception that the result of the work contributes to or is related to the more global objectives of the organization; information on the quality of work; perception of the position occupied by the professional within the organization and the relationship of this position with other intrinsic factors. Regarding the management of extrinsic factors, the needs are: to produce results in the research; recognition of individual performance; achievement of a career within the organization and the board profile.

Among the capitals surveyed, the most valuable indicator for scientific researchers and technologists was the structural capital, with the indicator topic "what to publish a book is worth", revealing that respondents perceive the over-rating in the publication of a book, as a criterion for maturity evaluation.

The product from this survey results shows an agreement with the CNPq indicators in the development of human resources with: focus on major social issues, environmental conservation and sustainability, communication with the society and with the international insertion, partnerships appeal, as well as concern with applications for patent validation.

The instrument proposed in this study may be used/adapted, using different samples in other contexts. Studies of adaptation and/or scale validation are, also, intrinsic from the future perspective.

\section{References}

Argyris, C. (1968). Personality and organization. Publishing Renes.

Bohlander, G., Snell, S., \& Sherman, A. (2003). Administração de Recursos Humanos (Human resource management). São Paulo: Pioneira Thonson Learning.

Chiavenato, I. (1999). Gestão de pessoas: o novo papel dos recursos humanos nas organizações (People management: The new role of human resources in organizations). Rio de Janeiro: Campus.

Chiavenato, I. (2005). Gestão de pessoas (People management). Rio de Janeiro: Ed. Elsevier.

Coda, R. (1986). Satisfação no Trabalho e Características das Políticas de Recursos Humano Para Executivos (Job satisfaction and characteristics of human resource policies for executives). Doctoral thesis. University of Sao Paulo.

Debora, D. B. A. M. (2014). A Retomada da Teoria do Capital Humano e da Produtividade da Escola - uma análise da atualidade da tese da produtividade da escola improdutiva (The resumption of the human capital theory and school productivity-An analysis of today's thesis productivity of unproductive school). MA dissertation. UFMS.

Decree 7133 of March 19, 2010. (2010). Regulates the general criteria and procedures to be followed for the realization of individual and institutional performance assessments and the payment of performance bonuses.

Deutscher, J. A. (2007). Assessing intangible capital. Business Intelligence Magazine, 31, 6.

Deutscher, J. A. (2008). Intangible capital. Doctoral thesis. COPPE, Federal University of Rio de Janeiro/UFRJ, Brazil.

Drucker, P. F. (1954). The practice of management. New York: Harpar \& Brothers.

Fernando, V. S. (2006). O perfil do servidor público na sociedade moderna (The profile of civil servants in modern society). Retrieved from http://bdjur.stj.jus.br/xmlui/bitstream/handle/2011/27248/perfil_servidor_publico_sociedade..pdf? sequence $=4$

Hipólito, J. A. M., \& Reis, G. G. (2002). The evaluation as a management tool. People in the organization (15th ed.). Editora Gente.

Kerzner, H. (2005). Using the management maturity model-Strategic planning for Project management. EUA: John Wiley \& Sons.

Law No. 10.973 of December 2, 2004. (2004). Which provides for incentives for innovation and technological scientific research in the production environment and other matters.

Law No. 11.784 of September 22, 2008. (2008). Provides for the restructuring of the general plan of positions of executive power. PGPE.

Law No. 8112 of December 11, 1990. (1990). Provides for the legal system of civil public servants of the union of municipalities and federal public foundations.

Law No. 9279 of May 14, 1996. (1996). Regulates rights and obligations relating to intellectual property. 
Law No. $9606 / 97$ of 19/02/1998. (1998). Provides for the protection of intellectual property computer program, its commercialization in the country, and other measures.

Law No. 9612 of 19/02/1998. (1998). Changes, updates and consolidates copyright law gives other providences.

Maroco, J. (2007). Análise estatística: com utilização do SPSS (Statistical analysis with use of SPSS) (3rd ed.). Lisboa: Edições Sílabo.

Maximiniano, A. C. A. (1995). The introduction to management. Sao Paulo, Atlas.

Pontes, B. R. (2010). Performance evaluation methods classic and contemporary, evaluation by objectives, skills and teams. Sao Paulo: Publisher LTr.

Rabaglio, M. O. (2004). Ferramentas de avaliação de performance com foco em competências (Performance assessment tools focusing on skills). Rio de Janeiro: Qualitymark.

Reifschneider, M. B. (2007). Considerações sobre Avaliação de Desempenho (Considerations performance evaluation). Retrieved from http://www.scielo.br/scielo.php

Rodrigues, H. Z., Tarouco, L. M. R., \& Klering, L. R. (2012). E-Maturity: entrelaçando gestão, tecnologia e pedagogia (E-Maturity: Interweaving management, technology and pedagogy). Retrieved from http://www.cinted.ufrgs. br/ciclo20/artigos/14a-herik.pdf

Silveira, V. N. S. (2009). Os Modelos Multiestágios de Maturidade: um Breve Relato de sua Historia, sua Difusão e sua Aplicação na Gestão de pessoas por meio do People Capability Maturity Model (P-CMM) [The multi models maturity stages: A brief account of its history, its diffusion and its application in the management of people through the People Capability Maturity Model (P-CMM)]. Retrieved from http://www.scielo.br/pdf/rac/v13n2/05.pdf

Susana, C. S., Filipa, A. C., Ana, P., Nelson, R., \& Antonio, C. (2009). A importância das características centrais do trabalho na satisfação com as recompensas (The importance of the central features of the job satisfaction with rewards). Sociologia, Problemas e prática (Sociology, Problems and Practice), 61, 10.

Vasconcelos, \& Krugliankas, I. (1991). Performance evaluation in research institutions. Journal of Management, 26(4), 73-86.

Wallace, Jr. M. J., \& Szilagyi, Jr. A. D. (1982). Managing behavior in organizations (p. 280). Scott Foresman and Company. 